\title{
USE OF OAK HAMMOCKS BY NEOTROPICAL MIGRANT SONGBIRDS: THE ROLE OF AREA AND HABITAT
}

\author{
SCOTT G. SOMERSHOE ${ }^{1,2}$ AND C. RAY CHANDLER ${ }^{1,3}$
}

\begin{abstract}
Many species of Neotropical migrant songbirds have declined in recent decades, due in part to loss and fragmentation of stopover habitat. To properly manage forested landscapes for migrating songbirds, information is needed on how size and habitat structure of forest patches influence their use by migrants during stopover. We conducted surveys of Neotropical migrant birds in eight oak hammocks of varying size $(0.32-3.08$ ha) at the Savannah National Wildlife Refuge, Jasper County, South Carolina during spring migration 1999 and 2000 and fall migration 1999. Hammock size was the most important factor related to number of total species, species per day, individuals per day, and density of migrants. Differences in vegetation structure and patchiness among hammocks did not explain differences in migrant abundance. Density of migrants tended to be higher in smaller hammocks, particularly during spring. Hammock use was generally similar between seasons and years. Two forest-interior breeding species occurred more often in the largest hammocks, suggesting that interior species are susceptible to forest fragmentation while en route. We suggest that protection of larger (versus smaller) tracts of forest is more beneficial to migrating songbirds, especially declining forest interior species. Received 22 April 2003, accepted 19 April 2004.
\end{abstract}

In recent decades many species of Neotropical migrant birds have undergone population declines (Faaborg and Arendt 1992, Gauthreaux 1992, Peterjohn et al. 1995). Although these declines may be linked to loss of habitat on the breeding grounds in North America and wintering grounds in Mexico, the Caribbean, and Central and South America (Robbins et al. 1989b, Askins et al. 1990), the loss of suitable stopover habitat has also been implicated (Moore et al. 1990). Thus, an important first step in managing land appropriately for en route migrant landbirds is to identify habitat features that are important in selection of stopover sites.

The maritime forests along the southeast Atlantic and Gulf coasts are a valuable resource for songbirds (Cohrs and Cohrs 1994, Moore et al. 1995). On the coasts of South Carolina, Georgia, and northernmost Florida, maritime forests are dominated by live oaks (Quercus virginiana), and occur as large contiguous patches of forest on barrier islands, the immediate mainland, and as small patches (oak hammocks) scattered among coastal marshes. Although contiguous patches of maritime forest occur on barrier islands and the

\footnotetext{
${ }^{1}$ Dept. of Biology, Georgia Southern Univ., Statesboro, GA 30460, USA

Current address: 2414 Drummond St., Apt. \#1, Vicksburg, MS 39180, USA.

${ }^{3}$ Corresponding author; e-mail: chandler@georgiasouthern.edu
}

adjacent mainland, oak hammocks are natural formations located on small $(<0.4-500$ ha) patches of well-drained soil among coastal marshes isolated from other oak hammocks and forests. In six coastal Georgia counties, more than 1,200 oak hammocks have been identified, with $85 \%$ of these smaller than 4 ha (Georgia Department of Natural Resources 2002). The rising value of coastal property has led to development of large patches of maritime forest (large oak hammocks and barrier islands) as well as smaller and more isolated hammocks (U.S. Fish and Wildlife Service 1993, Georgia Department of Natural Resources 2002).

As development reduces the amount of maritime forest cover, migrant birds may experience reduced refueling rates and may incur increased en route mortality (Petit 2000). Stopover ecology of Neotropical migrant songbirds along the southeastern coast has received little attention despite recent songbird declines and rapid coastal development. In addition, no studies have been conducted on songbird use of hammocks during migration. Hammocks are accessible only by boat and the expense and difficulty in accessing hammocks has prevented thorough songbird studies from being conducted. Oak hammocks may be critical habitat for Neotropical migrant songbirds (Cox 1988), but little is known about how migrants use hammocks during stopover (Hillestad et al. 1975, Cox 1988, 
Cohrs and Cohrs 1994). Lack of knowledge on hammock use by migrants may hamper appropriate management of this habitat along the coast of the southeastern United States.

A representative example of oak hammocks along the southeastern coast occurs at Savannah National Wildlife Refuge (SNWR), Jasper County, South Carolina. Several hammocks are readily accessible via a series of impoundments used to control water levels. Hammock size distribution and vegetative communities are similar to those found elsewhere in Georgia and along the southeastern Atlantic coast (Georgia Department of Natural Resources 2002), making SNWR an ideal location to study songbird migration.

We assessed migrant stopover use of oak hammocks to determine whether (1) abundance of migrating Neotropical songbirds increases with hammock size, (2) vegetation structure influences the abundance and diversity of migrants, and (3) edge and forest interior species use hammocks differently.

\section{METHODS}

Study area.-We conducted our study from April 1999 through May 2000 at the SNWR $\left(32^{\circ} 15^{\prime} \mathrm{N}, 81^{\circ} 11^{\prime} \mathrm{W}\right)$, Jasper County, South Carolina. The study site is located on the lower coastal plain approximately $16 \mathrm{~km}$ from the Atlantic Ocean and comprises 4,306 ha of freshwater marsh and scattered forest. We located 11 oak hammocks on SNWR that were accessible from a series of impoundments used to control water levels. We selected eight of these hammocks for surveys so as to span the range in size of fragments $(0.32,0.57$, $1.05,1.13,1.29,1.70,1.86$, and 3.08 ha) at SNWR; this range represents most hammocks in the coastal region. Study hammocks were isolated from one another by $>0.4 \mathrm{~km}$ of freshwater marsh and were located 1.6-3.0 $\mathrm{km}$ from adjacent forests. Hammock isolation reduced movement of migrants among hammocks and adjacent forests during surveys. The three hammocks not selected were difficult to access or near adjacent forest. We measured the area of each fragment $( \pm 5 \%)$ with a Corvallis Microtechnology MC-V Global Positioning System differentially corrected to the Charleston, South Carolina base station.

Bird surveys.-During spring 1999 and 2000 (10 April-12 May), we surveyed birds in each hammock 26-29 times, and, during fall 1999 migration (25 September-30 October), we surveyed each of five hammocks 23 times. Surveys were conducted 4-5 times weekly. We surveyed fewer hammocks in fall to allow for an increased number of surveys per hammock in one field season. We chose the two largest and two smallest hammocks for surveys during fall migration and randomly chose a fifth (1.29 ha) from the remaining four hammocks.

We estimated songbird abundance and diversity using a modified line transect. Because some study plots were small $(<0.6$ ha), we could not use standard point or line transect techniques and therefore did not collect distance data. We conducted our surveys along a pre-selected circular path through the generally round forest patches. We followed a path that allowed for an audible and/or visual survey of the entire hammock and recorded the presence of all birds observed within the hammock. Survey duration varied among hammocks, however we surveyed each hammock with constant effort per unit area $(\sim 2.1 \mathrm{ha} / \mathrm{hr})$. We followed the same route during each survey. Vegetation height, structure, and density were similar among hammocks, thus our ability to detect birds within and among hammocks was similar. We surveyed hammocks in random order during the first $3.5 \mathrm{hr}$ after local sunrise. We did not conduct surveys during rain or when winds were $>24 \mathrm{~km} / \mathrm{hr}$. We defined Neotropical migrants according to Hunter et al. (1993).

The migrants recorded in this study likely spent most of the day in the hammock where they were observed; thus, surveys were independent on each day. We based this on the following: (1) we recorded only one instance of migrants moving between hammocks during surveys; (2) migrants often complete nocturnal flight before civil twilight (Graber 1968, Able 1970, Bellrose 1971), so most of the movement between hammocks probably occurred before we began the first survey after sunrise each morning; and (3) migrants typically move only short distances during stopover (Aborn and Moore 1997; J. Farrington pers. comm.; J. Buler pers. comm.).

We attempted to avoid recounting individuals within a hammock during each survey. In spring, a small number of migrants discontin- 
ued migration and became summer residents during our survey period. If we repeatedly observed an individual of any locally breeding Neotropical species in the same location exhibiting nesting behavior (e.g., courtship, nest building), we considered the bird a local breeder and removed the individual from migration surveys. We conducted surveys to quantify the breeding bird community in each hammock during late May and early June, confirmed local breeding pairs, and removed those birds $(<20$ birds) from our migration surveys. We removed no birds from fall surveys because we conducted all surveys after the breeding season, and few individuals were winter residents (SGS pers. obs.). We suspect some birds held territories during both spring and fall migration and the same individual may have been recorded on multiple surveys. The lack of temporal independence is inherent in all migration studies involving surveys of unbanded birds, however, from our observations we suspect daily turnover rates were large $(>90 \%)$ in all hammocks, with few individuals staying for multiple days. All surveys were conducted by the same individual (SGS).

Habitat characteristics. - We quantified habitat within each hammock in spring 1999 following James and Shugart (1970). We used 0.04 ha plots to quantify $\geq 25 \%$ of the area of each hammock. We measured (1) basal area of trees $\geq 10 \mathrm{~cm}$ diameter at breast height (dbh), (2) percent canopy cover, (3) percent herbaceous ground cover, (4) litter depth, (5) number of trees $\geq 10 \mathrm{~cm} \mathrm{dbh}$, (6) number of yaupon (Ilex vomitoria) stems $<10 \mathrm{~cm} \mathrm{dbh}$, and (7) number of other stems $<10 \mathrm{~cm} d b h$. We estimated yaupon stem density separately because yaupon is the dominant understory plant and it may provide fruit resources for fall migrants (Grimm 1983).

The canopies of the oak hammocks were dominated by mature oaks ( $Q$. virginiana, $Q$. laurifolia, and $Q$. nigra), sweetgum (Liquidambar styraciflua), sugarberry (Celtis laevigata), chinaberry (Melia azedarach), and Chinese tallow (Sapium sebiferum). Pines (Pinus elliottii, P. palustris) and bald cypress (Taxodium distichum) were present, but were a minor part of the canopy. Understory vegetation was comprised primarily of yaupon, cherry laurel (Prunus caroliniana), red maple (Acer rubrum), saw palmetto (Serenoa repens), greenbrier (Smilax spp.), mulberry (Morus spp.), wax myrtle (Myrica cerifera), and beautyberry (Callicarpa americana).

Statistical analyses.-We checked data for normality and homogeneous variances before conducting parametric tests. We used paired $t$ tests (data paired by hammocks) to examine differences in number of species per day, individuals per day, and density of migrants between years and seasons. We used linear regression to assess whether migrants consistently preferred certain hammocks across years or seasons. We used ANOVA to test for added variance among hammocks in number of individuals and species per day (abundance) and density (number of individuals per ha). The added variance addresses random effects varying among groups (individual hammocks) and partitions variation into two types: (1) day-to-day variation within hammocks, and (2) variation among hammocks.

We used principal components analysis (PC) of the correlation matrix of the original habitat variables to reduce vegetation data into fewer variables. For those PC axes with eigen values $>1$, we calculated mean PC scores and the variance in $\mathrm{PC}$ scores for each hammock and then used ANOVA to test for vegetation differences based on PC scores.

To assess the effects of area (log transformed) and vegetation structure on the number of species per day, individuals per day, and density we used least-squares linear regression. Slope $(b)$ represents the direction of the relationship between hammock size or vegetation and the associated variable (abundance or density). A positive slope indicates a direct relationship, while a negative slope indicates an inverse relationship between the treatment (hammock size or PC score) and the variable (abundance or density). Analysis of how individual species used hammocks of varying size and vegetation structure included only species recorded on $\geq 7 \%$ of all counts during the season being analyzed. We set $\alpha=$ 0.05 and conducted all statistical analyses using JMP 3.02 Statistical Software (SAS Institute, Inc. 1995).

\section{RESULTS}

We recorded 41 Neotropical species with a mean of $27.4 \pm 2.8$ (SE) individuals per day 
TABLE 1. Richness, abundance, and density of Neotropical migrants in oak hammocks at the Savannah National Wildlife Refuge, Jasper County, South Carolina, 1999-2000.

\begin{tabular}{|c|c|c|c|c|c|c|c|c|}
\hline & \multicolumn{8}{|c|}{ Hammock area (ha) } \\
\hline & 0.32 & 0.57 & 1.05 & 1.13 & 1.29 & 1.70 & 1.86 & 3.08 \\
\hline \multicolumn{9}{|l|}{ Spring 1999} \\
\hline Total species per season & 15 & 12 & 16 & 22 & 14 & 19 & 27 & 25 \\
\hline Mean number of species per day & 2.3 & 2.7 & 3.2 & 3.9 & 2.1 & 4.3 & 6.5 & 5.7 \\
\hline Mean number of individuals per day & 3.1 & 4.4 & 5.2 & 6.7 & 4.1 & 7.3 & 11.3 & 8.3 \\
\hline Mean density (number per ha) & 9.6 & 7.7 & 5.0 & 5.9 & 3.2 & 4.3 & 6.1 & 2.7 \\
\hline \multicolumn{9}{|l|}{ Fall 1999} \\
\hline Total species per season & 12 & 12 & & & 18 & & 21 & 21 \\
\hline Mean number of species per day & 3.0 & 2.9 & & & 4.0 & & 5.4 & 8.3 \\
\hline Mean number of individuals per day & 7.2 & 5.9 & & & 9.2 & & 12.6 & 32.9 \\
\hline Mean density (number per ha) & 22.5 & 10.4 & & & 7.1 & & 6.8 & 10.6 \\
\hline \multicolumn{9}{|l|}{ Spring 2000} \\
\hline Total species per season & 12 & 16 & 18 & 20 & 16 & 19 & 21 & 21 \\
\hline Mean number of species per day & 2.2 & 2.7 & 3.2 & 3.0 & 3.2 & 3.0 & 3.9 & 6.3 \\
\hline Mean number of individuals per day & 4.0 & 4.5 & 4.7 & 3.8 & 4.4 & 3.9 & 5.3 & 10.1 \\
\hline Mean density (number per ha) & 12.5 & 7.9 & 4.5 & 3.4 & 3.4 & 2.3 & 2.8 & 3.3 \\
\hline
\end{tabular}

(sum for all hammocks) during spring migration. We recorded 30 species with a mean of $67.3 \pm 7.9$ (SE) individuals per day (sum for all hammocks) during fall. See Somershoe (2000) for a complete species list.

During spring, the abundance and density of migrants per day did not differ among years. Density of migrants $\left(F_{1,7}=12.92, P=\right.$ $\left.0.011, R^{2}=0.68\right)$ in each hammock in 2000 could be predicted from 1999. On the other hand, number of species per day $\left(F_{1,7}=5.08\right.$, $\left.P=0.064, R^{2}=0.46\right)$ and individuals per day $\left(F_{1,7}=1.21, P=0.32, R^{2}=0.17\right)$ were less predictable from year to year. Hammocks sampled in spring and fall $(n=5)$ were used similarly in terms of number of species per day $\left(F_{1,4}=15.07, P=0.030, R^{2}=0.83\right)$ and density $\left(F_{1,4}=12.14, P=0.040, R^{2}=0.80\right)$, but the number of individuals per day $\left(F_{1,4}=\right.$ $15.12, P=0.067, R^{2}=0.73$ ) was less predictable between seasons.

Richness, abundance, and density of Neotropical migrants varied among hammocks (Table 1). During spring, $81-90 \%$ of the variation in species per day, number of individuals per day, and density of Neotropical migrants was attributable to consistent day-today differences within hammocks. During fall, $46-71 \%$ of the variation in abundance and density was explained by differences within hammocks.
We detected a significant relationship between hammock area and number of total species, species per day, individuals per day, and density of migrants in both spring 1999 and 2000 , except for number of individuals per day in spring 2000 (Table 2). Total species per season and species per day were the only variables that varied by area during fall 1999 . Larger hammocks attracted more species and more individuals (positive slope); smaller hammocks tended to hold a higher density of migrants (negative slope; Table 2).

Three principal components accounted for $63.8 \%$ of the total variation in vegetation. PC1 described a gradient from relatively open forest with large amounts of herbaceous ground cover to denser forest with deep litter and smaller amounts of herbaceous ground cover (27.8\% of the variation). The gradient described by PC2 ranged from large amounts of total basal area and yaupon stems to areas with large numbers of trees and other stems (21.5\% of the variation). PC3 depicted a trend from large numbers of other stems and a complete canopy to areas with a large mean litter depth (14.5\% of the variation). Vegetation structure differed significantly among hammocks only along the first principal component axis $\left(F_{7.56}=5.77, P=0.001\right)$, while no significant differences were found along PC2 $\left(F_{7,56}=1.74, P=0.13\right)$ and $\mathrm{PC} 3\left(F_{7,56}=\right.$ 
TABLE 2. Linear regressions of hammock area on the number of species per season, species per day, individuals per day, and density of Neotropical migrants among hammocks at the Savannah National Wildlife Refuge, Jasper County, South Carolina, 1999-2000. $R^{2}$ values represent amount of variation in species per season, mean species per day, individuals per day, and density explained by among-hammock variation in area; $b$ values represent the slope of the relationship between hammock area and the associated variable.

\begin{tabular}{|c|c|c|c|c|c|c|c|c|c|}
\hline & \multicolumn{3}{|c|}{ Spring 1999} & \multicolumn{3}{|c|}{ Fall 1999} & \multicolumn{3}{|c|}{ Spring 2000} \\
\hline & $P$ & $R^{2}$ & $b$ & $P$ & $R^{2}$ & $b$ & $P$ & $R^{2}$ & $b$ \\
\hline Total species per season & 0.044 & 0.52 & 12.8 & 0.011 & 0.91 & 11.0 & 0.002 & 0.82 & 12.2 \\
\hline Number of species per day & 0.034 & 0.55 & 3.9 & 0.046 & 0.78 & 5.0 & 0.015 & 0.65 & 3.3 \\
\hline Number of individuals per day & 0.029 & 0.57 & 6.6 & 0.12 & 0.61 & 21.9 & 0.10 & 0.38 & 4.2 \\
\hline Density (number per ha) & 0.020 & 0.62 & -6.1 & 0.17 & 0.52 & -11.7 & 0.002 & 0.81 & -10.4 \\
\hline
\end{tabular}

1.96, $P=0.082$ ). The structure (mean PC score) and patchiness (variance in PC scores) of the vegetation in hammocks was unrelated to variation in richness, abundance, and density of migrants in both spring and fall (all $P$ $\geq 0.18$; Table 3 ).

We recorded 12 species during spring and 11 species during fall on at least $7 \%$ of all counts (Table 4). Although eight species showed significant relationships between numbers of individuals per day and hammock area in spring, little variation in the relationship was accounted for by hammock area (all $R^{2} \leq 0.07$ ). Of 10 species detected significantly more often in large hammocks during the fall, Eastern Wood-Pewee (Contopus virens; $\left.\mathrm{P}<0.001, R^{2}=0.27\right)$, Blue-gray Gnatcatcher (Polioptila caerulea; $P<0.001, R^{2}=$ 0.22), American Redstart (Setophaga ruticilla;
$P<0.001, R^{2}=0.27$ ), and Northern Waterthrush (Seiurus noveboracensis; $P<0.001, R^{2}$ $=0.39$ ) had substantive amounts of variation explained by the regression. We also found an interesting distribution of several species across hammocks. During spring, we did not detect Northern Waterthrushes in the smallest hammock, detected them only once in the next smallest hammock $(0.57$ ha), but we detected them regularly in the larger hammocks. During fall, we found four species in only the three largest hammocks: Eastern Wood-Pewee, Northern Parula (Parula americana), Palm Warbler (Dendroica palmarum), and Northern Waterthrush. We detected Eastern Wood-Pewee and Northern Waterthrush in the largest hammock on 71 and $96 \%$ of all counts, respectively, and did not record them on any counts in the two smallest hammocks. A sig-

TABLE 3. Linear regressions of PC1 score (vegetation structure) and variance in PC1 score (vegetation patchiness) on the number of species per season, species per day, individuals per day, and density of Neotropical migrants among hammocks at the Savannah National Wildlife Refuge, Jasper County, South Carolina, 19992000. Abundance, richness, and density were not related to vegetation structure (all $P \geq 0.18$ ). $R^{2}$ values represent amount of variation in number of species per season, species per day, individuals per day, and density explained by among-hammock variation in vegetation; $b$ values represent the slope of the relationship between vegetation structure or vegetation patchiness and the associated variable.

\begin{tabular}{|c|c|c|c|c|c|c|c|c|c|}
\hline & \multicolumn{3}{|c|}{ Spring 1999} & \multicolumn{3}{|c|}{ Fall 1999} & \multicolumn{3}{|c|}{ Spring 2000} \\
\hline & $P$ & $R^{2}$ & $b$ & $P$ & $R^{2}$ & $b$ & $P$ & $R^{2}$ & $b$ \\
\hline \multicolumn{10}{|l|}{ Vegetation structure } \\
\hline Total species per season & 0.67 & 0.03 & -0.90 & 0.64 & 0.08 & 0.99 & 0.84 & 0.01 & -0.32 \\
\hline Number of species per day & 0.55 & 0.06 & -0.37 & 0.83 & 0.02 & -0.22 & 0.99 & 0.00 & -0.01 \\
\hline Number of individuals per day & 0.81 & 0.01 & -0.25 & 0.70 & 0.06 & -1.99 & 0.75 & 0.01 & -0.26 \\
\hline Density (number per ha) & 0.18 & 0.28 & -1.15 & 0.22 & 0.44 & -3.18 & 0.49 & 0.08 & -0.07 \\
\hline \multicolumn{10}{|l|}{ Vegetation patchiness } \\
\hline Total species per season & 0.31 & 0.17 & -1.15 & 0.99 & 0.00 & 0.02 & 0.30 & 0.17 & -0.89 \\
\hline Number of species per day & 0.19 & 0.26 & -0.42 & 0.63 & 0.09 & -0.29 & 0.74 & 0.02 & -0.09 \\
\hline Number of individuals per day & 0.28 & 0.19 & -0.60 & 0.59 & 0.10 & -1.54 & 0.71 & 0.02 & -0.17 \\
\hline Density (number per ha) & 0.54 & 0.07 & -0.31 & 0.84 & 0.02 & -0.34 & 0.89 & 0.00 & 0.13 \\
\hline
\end{tabular}


TABLE 4. Linear regressions of hammock area (ha) and vegetation structure (mean PC1 score) on the number of Neotropical migrant individuals per day among hammocks at the Savannah National Wildlife Refuge, Jasper County, South Carolina, 1999-2000. We detected substantial variation $\left(R^{2}>0.22\right)$ between hammock area and daily abundance for four species during fall 1999 migration (boldface). Neither hammock area nor vegetation structure explained much of the variation in daily abundance for other species in either season (all $R^{2} \leq 0.18$ ). Species lacking information for either spring or fall indicate that minimum occurrence criteria were not satisfied (see text).

\begin{tabular}{|c|c|c|c|c|c|c|c|c|c|c|}
\hline \multirow[b]{3}{*}{ Species } & \multicolumn{5}{|c|}{$\begin{array}{c}\text { Combined spring } \\
1999 \text { and } 2000\end{array}$} & \multicolumn{5}{|c|}{ Fall 1999} \\
\hline & \multirow{2}{*}{$\begin{array}{c}\% \\
\text { counts }^{\mathrm{a}}\end{array}$} & \multicolumn{2}{|c|}{ Area } & \multicolumn{2}{|c|}{$\begin{array}{l}\text { Vegetation } \\
\text { structure }\end{array}$} & \multirow{2}{*}{$\begin{array}{c}\% \\
\text { counts }^{\mathrm{a}}\end{array}$} & \multicolumn{2}{|c|}{ Area } & \multicolumn{2}{|c|}{$\begin{array}{l}\text { Vegetation } \\
\text { structure }\end{array}$} \\
\hline & & $P$ & $R^{2}$ & $P$ & $R^{2}$ & & $P$ & $R^{2}$ & $P$ & $R^{2}$ \\
\hline Contopus virens $^{\mathrm{b}}$ & & & & & & 25 & $<\mathbf{0 . 0 0 1}$ & 0.27 & 0.70 & 0.00 \\
\hline Myiarchus crinitus ${ }^{\mathrm{b}}$ & 30 & 0.099 & 0.03 & 0.99 & 0.00 & & & & & \\
\hline Tyrannus tyrannus ${ }^{\mathrm{b}}$ & 33 & 0.044 & 0.02 & $<0.001$ & 0.05 & & & & & \\
\hline Vireo griseus ${ }^{\mathrm{b}}$ & & & & & & 30 & 0.001 & 0.12 & 0.82 & 0.00 \\
\hline Polioptila caerulea $^{\mathrm{b}}$ & 28 & $<0.001$ & 0.07 & 0.01 & 0.05 & 39 & $<\mathbf{0 . 0 0 1}$ & 0.22 & 0.57 & 0.00 \\
\hline Dumetella carolinensis ${ }^{\mathrm{b}}$ & 32 & 0.25 & 0.00 & 0.29 & 0.01 & 74 & 0.003 & 0.08 & 0.62 & 0.00 \\
\hline Parula americana ${ }^{\mathrm{b}}$ & 21 & $<0.001$ & 0.06 & 0.13 & 0.01 & 17 & 0.001 & 0.09 & 0.005 & 0.07 \\
\hline Dendroica caerulescens ${ }^{\mathrm{c}}$ & 16 & 0.005 & 0.03 & 0.57 & 0.00 & 14 & 0.68 & 0.00 & 0.11 & 0.02 \\
\hline Dendroica palmarum ${ }^{\text {b }}$ & & & & & & 9 & 0.004 & 0.07 & 0.54 & 0.00 \\
\hline Dendroica striata ${ }^{\mathrm{c}}$ & 9 & 0.005 & 0.03 & 0.61 & 0.00 & & & & & \\
\hline Mniotilta varia ${ }^{\mathrm{c}}$ & 15 & 0.003 & 0.04 & 0.83 & 0.00 & & & & & \\
\hline Setophaga ruticilla ${ }^{\mathrm{c}}$ & 22 & 0.10 & 0.01 & 0.94 & 0.00 & 61 & $<0.001$ & 0.27 & 0.07 & 0.03 \\
\hline Seiurus noveboracensis ${ }^{\mathrm{b}}$ & 7 & $<0.001$ & 0.07 & 0.31 & 0.00 & 33 & $<0.001$ & 0.39 & 0.13 & 0.02 \\
\hline Geothlypis trichas ${ }^{\mathrm{b}}$ & 50 & 0.007 & 0.03 & 0.08 & 0.01 & 57 & $<0.001$ & 0.18 & 0.032 & 0.04 \\
\hline Passerina cyanea ${ }^{\mathrm{d}}$ & & & & & & 57 & $<0.001$ & 0.12 & 0.13 & 0.02 \\
\hline Icterus spurius $^{\mathrm{d}}$ & 23 & 0.92 & 0.00 & 0.13 & 0.01 & & & & & \\
\hline
\end{tabular}

a Percent occurrence over all counts.

b Interior species.

c Interior/edge species.

${ }^{d}$ Edge/scrub species (definitions follow Whitcomb et al. 1981, Robbins et al. 1989a, Holmes 1994, Wilson 1996),

nificant relationship between individuals per day and vegetation structure was detected for a few species, but only a small amount of the variation was explained by vegetation (all $R^{2}$ $\leq$ 0.07; Table 4).

\section{DISCUSSION}

Larger oak hammocks along the South Carolina coast attract larger numbers of species, species per day, and individuals per day, while smaller hammocks tend to have higher densities of migrants. A substantial portion of variation in migrant abundance and density in spring was due to day-to-day differences within hammocks, while among hammock variation explained migrant distribution in fall. This implies that there are features of oak hammocks that are predictably associated with use by Neotropical migrants.

One of the features is clearly size: larger hammocks contained more species and more individuals. Others also have found a positive species-area relationship for migrant birds in forest patches (Martin 1980, Cox 1988). The simplest explanation for this pattern is that migrants sort into hammocks at random as they arrive over the study area. If so, density of migrants should be similar among hammocks of different size. Our results show that large hammocks attract more individuals but small hammocks support higher densities of migrants (Tables 1,2), which is inconsistent with random sorting (Martin 1980). Because many migrants discontinue nocturnal flight before sunrise, they may randomly choose a hammock upon landing and select more suitable habitat or hammocks before sunrise. As a result, we might expect the distribution of migrants after hammock selection to be nonrandom, as we found.

Although Martin (1980) suggested that habitat diversity may be a better predictor of abundance of migrants than area, we did not detect a relationship between vegetation structure and migrant richness, abundance, or density. Although migrants exhibit habitat pref- 
erences (Bairlein 1983, Lindström 1989), at the scale of our analysis, among-hammock sorting of the migrant assemblage was not correlated to features of the vegetation.

If songbirds select migratory habitat in a way that is similar to how they select breeding habitat (Petit 2000), forest interior specialists also may show preferences for larger forest patches along the migration route (Whitcomb et al. 1981). Six species (Eastern Wood-Pewee, Blue-gray Gnatcatcher, Northern Parula, Palm Warbler, American Redstart, and Northern Waterthrush) were found most often in large hammocks; thus, small hammocks $(<0.5$ ha) may not provide adequate habitat. This suggests that fragmentation of forested stopover sites may be detrimental to these species. Species such as the Eastern Wood-Pewee, which is declining in the eastern portion of its range (Breeding Bird Survey; Peterjohn et al. 1995), might suffer from the effects of fragmentation en route as well as on the breeding and wintering grounds.

Number of individuals per day, likely the most variable of measurements, differed between seasons and years because of the large variation in the daily number of individuals inherent in studies of migration. Although sources of variation in migrant abundance and density among hammocks differed between seasons, general patterns of similar numbers of species per day and density between years and seasons suggest that migrants are using similar criteria in selecting hammocks. The hammocks at SNWR are similar to others found in South Carolina and along the southeastern Atlantic coast. Thus, consistent patterns in bird abundance and density between years and seasons may be applicable to other hammocks and our data may provide reliable information for developing management guidelines.

Although oak hammocks are not remnants of larger, contiguous forest, migrants likely use the same criteria in selecting hammocks and fragments of maritime forest. Development on barrier islands will fragment contiguous maritime forest, resulting in small patches of forest surrounded by unsuitable habitat (i.e., houses, roads, etc.). Many of these new fragments will be of comparable size to natural oak hammocks and the observed patterns of migrant richness, abundance, and density in hammocks at SNWR may apply to these new fragments.

Our results suggest that management should emphasize preserving all hammocks for migrating songbirds; however, larger hammocks may be more beneficial to forest interior species. Future research should address the issues of habitat use, resource availability, and stopover success in hammocks and remnant forest fragments.

\section{ACKNOWLEDGMENTS}

We thank S. Drake and J. Robinette of the Georgia Coastal Fish and Wildlife Service for providing permission to conduct this research at SNWR. R. Webb of the Georgia Coastal Fish and Wildlife Service provided logistical support. D. F. Gleason, A. W. Harvey, S. P. Hudman, and A. A. Kinsey provided critical review and support. D. A. Aborn, S. P. Hudman, and three anonymous reviewers greatly improved the manuscript. C. Spine generously provided support while working on this manuscript. Funding to SGS was provided by an E. Alexander Bergstrom Memorial Research Award from the Association of Field Ornithologists, an H. Branch Howe, Jr., Research Award from the Georgia Ornithological Society, and an Academic Excellence Award and Graduate Student Professional Development Fund Grants through Georgia Southern University.

\section{LITERATURE CITED}

ABLE, K. P. 1970. A radar study of the altitude of nocturnal passerine migration. Bird-banding 41:282290.

AbORn, D. A. AND F. R. MoORE. 1997. Pattern of movement by Summer Tanagers (Piranga rubra) during migratory stopover: a telemetry study. Behaviour 134:1077-1100.

Askins, R. A., J. F. LynCh, And R. Greenberg. 1990. Population declines in migratory birds in eastern North America. Current Ornithology 7:1-57.

BAIRLEIN, F. 1983. Habitat selection and associations of species of European passerine birds during southward, post-breeding migrations. Ornis Scandinavica 14:239-245.

Bellrose, F. C. 1971. The distribution of nocturnal migrants in the air space. Auk 88:397-424.

Cohrs, D. AND D. CoHrs. 1994. Sixteen years of banding birds during fall migration on Jekyll Island, Georgia. Oriole 59:37-48.

Cox, J. 1988. The influence of forest size on transient and resident bird species occupying maritime hammocks of northeastern Florida. Florida Field Naturalist 16:25-34.

FAABORG, J. And W. J. ARendt. 1992. Long-term declines of winter resident warblers in Puerto Rican dry forest: which species are in trouble? Pages 57-63 in Ecology and conservation of Neotropical migrant landbirds (J. M. Hagan, III, and D. W. 
Johnson, Eds.). Smithsonian Institution Press, Washington, D.C.

Gauthreaux, S. A., JR. 1992. The use of weather radar to monitor long-term patterns of trans-Gulf migration in spring. Pages 96-100 in Ecology and conservation of Neotropical migrant landbirds (J. M. Hagan, III, and D. W. Johnson, Eds.). Smithsonian Institution Press, Washington, D.C.

Georgia Department of Natural Resources. 2002. Report of the Coastal Marsh Hammocks Advisory Council. Online at $<$ http://alpha.marcsi.uga.edu/ coastalcouncil/hammck_rpt.pdf $>$ (accessed November 2003).

GRABER, R. R. 1968. Nocturnal migration in Illinoisdifferent points of view. Wilson Bulletin 80:3671.

GrimM, W. C. 1983. The illustrated book of trees: the comprehensive field guide to more than 250 trees of eastern North America. Stackpole Books, Mechanicsburg, Pennsylvania.

Hillestad, H. O., J. R. Bozeman, A. S. Johnson, C. W. Berisford, AND J. T. Richardson. 1975. The ecology of Cumberland Island National Seashore, Camden County, Georgia. Florida Sea Grant, Technical Report Series, no. 75-6, Tallahassee, Florida.

Holmes, R. T. 1994. Black-throated Blue Warbler (Dendroica caerulescens). The Birds of North America, no. 87.

Hunter, W. C., M. F. Carter, D. N. Pashley, and K. BARKer. 1993. The Partners in Flight species prioritization scheme. Pages 109-119 in Status and management of Neotropical migratory birds (D. M. Finch and P. W. Stangel, Eds.). General Technical Report RM-229. U.S. Forest Service, Rocky Mountain Forest and Range Experiment Station, Fort Collins, Colorado.

James, F. C. And H. H. Shugart, JR. 1970. A quantitative method of habitat description. Audubon Field Notes 24:727-735.

LiNDSTRÖM, А. 1989. Finch flock size and risk of hawk predation at a migratory stopover site. Auk 106: $225-232$.

MARTIN, T. E. 1980. Diversity and abundance of spring migratory birds using habitat islands on the Great Plains. Condor 82:430-439.

Moore, F. R., S. A. Gauthreaux, Jr., P. Kerlinger, AND T. R. Simons. 1995. Habitat requirements dur- ing migration: important link in the conservation of Neotropical landbird migrants. Pages 121-144 in Ecology and management of Neotropical migratory birds: a synthesis and review of critical issues (T. E. Martin and D. M. Finch, Eds.). Oxford University Press, New York.

Moore, F. R., P. Kerlinger, and T. R. Simons. 1990. Stopover on a Gulf coast barrier island by spring trans-gulf migrants. Wilson Bulletin 102:487-500.

Peterjohn, B. G., J. R. Sauer, and C. S. Robbins. 1995. Population trends from the North American Breeding Bird Survey. Pages 3-39 in Ecology and management of Neotropical migratory birds: a synthesis and review of critical issues (T. E. Martin and D. M. Finch, Eds.). Oxford University Press, New York.

Petit, D. R. 2000. Habitat use by landbirds along Nearctic-Neotropical migration routes: implications for conservation of stopover habitats. Studies in Avian Biology 20:15-33.

Robbins, C. S., D. K. Dawson, and B. A. Dowell. 1989a. Habitat area requirements of breeding forest birds of the middle Atlantic states. Wildlife Monographs, no. 103.

Robbins, C. S., J. R. Sauer, R. S. Greenberg, and S. Droege. 1989b. Population declines in North American birds that migrate to the Neotropics. Proceedings of the National Academy of Sciences 86:7658-7662.

Sas Institute, InC. 1995. JMP statistics and graphics guide, ver. 3.1. SAS Institute Inc., Cary, North Carolina.

Somershoe, S. G. 2000. Use of oak hammocks by Neotropical migrant songbirds during stopover in coastal South Carolina. M.Sc. thesis, Georgia Southern University, Statesboro.

U.S. Fish AND Wildlife Service. 1993. Meeting our coastal challenges. Special Report, U.S. Fish Wildlife Service, Branch of Coastal and Wetland Resources, Arlington, Virginia.

Whitcomb, R. F., C. S. Robbins, J. F. Lynch, B. L. Whitcomb, M. K. KLIMKIEWICZ, AND D. Bystrak. 1981. Effects of forest fragmentation on avifauna of the eastern deciduous forest. Pages 125-206 in Forest island dynamics in man-dominated landscapes (R. L. Burgess and B. M. Sharpie, Eds.). Springer-Verlag, New York.

Wilson, W. H., JR. 1996. Palm Warbler (Dendroica palmarum). The Birds of North America, no. 238. 


\section{$2 \mathrm{BHL}$ Biodiversity Heritage Library}

Somershoe, Scott G and Chandler, C. Ray. 2004. "Use of Oak Hammocks by Neotropical Migrant Songbirds: The Role of Area and Habitat." The Wilson bulletin 116(1), 56-63.

View This Item Online: https://www.biodiversitylibrary.org/item/214670

Permalink: https://www.biodiversitylibrary.org/partpdf/209835

\section{Holding Institution}

Harvard University, Museum of Comparative Zoology, Ernst Mayr Library

\section{Sponsored by}

IMLS LG-70-15-0138-15

\section{Copyright \& Reuse}

Copyright Status: In copyright. Digitized with the permission of the rights holder.

Rights Holder: Wilson Ornithological Society

License: http://creativecommons.org/licenses/by-nc-sa/4.0/

Rights: https://biodiversitylibrary.org/permissions

This document was created from content at the Biodiversity Heritage Library, the world's largest open access digital library for biodiversity literature and archives. Visit BHL at https://www.biodiversitylibrary.org. 